DOI: $10.14720 /$ aas.2016.107.1.12

Agrovoc descriptors: pregermination; seed treatment; potassium; germinability; germination; seed germinability, seed vigour; zea mays; maize; drought stress; drought tolerance

Agris category code: f40, f04, f62

\title{
Germination and seedling characteristics of drought-stressed corn seed as influenced by seed priming with potassium nano-chelate and sulfate fertilizers
}

\author{
Maryam ZAHEDIFAR $^{1 *}$ and Sadegh ZOHRABI ${ }^{1}$
}

Received May 08, 2015; accepted February 22, 2016.

Delo je prispelo 08. maja 2015, sprejeto 22. februarja 2016.

\begin{abstract}
Effect of seed-priming with potassium $(\mathrm{K})$ sources (K-nanochelate, $\mathrm{KNC}$, and sulfate $(0,2$ and $4 \%))$ under drought stress (DS) conditions $(0,-0.3,-0.6,-0.9,-1.2$ and $-1.5 \mathrm{MPa}$ water potential) on the corn seedling traits was studied. Drought stress decreased the germination indices and seedling vigor. The highest germination, seminal root fresh and dry mass (RFM and RDM) was obtained in KNC primed seeds at $0.3 \mathrm{MPa}$ DS. Mean germination time increased under DS conditions mainly in non-primed seeds. Increasing DS to 1.2 MPa led to decrease in RFM and RDM. Influence of DS on the fresh mass of shoots was more severe than on seminal roots. The highest shoots and seminal roots length was observed in $4 \% \mathrm{KNC}$ without any DS. Proper priming can be suggested to increase the plant tolerance under DS.
\end{abstract}

Key words: germination percentage, vigor index, seed priming, corn, shoots and seminal roots fresh and dry mass

\section{IZVLEČEK}

VPLIV PREDTRETIRANJA SEMEN KORUZE K KALIJEVIM NANO HELATOM IN SULFATOM NA KALITEV IN LASTNOSTI KALIC V RAZMERAH SUŠNEGA STRESA

$\mathrm{V}$ raziskavi so bili preučevani učinki predtretiranja semen koruze s kalijevim nano helatom $(\mathrm{KNC})$ in $\mathrm{K}$-sulfatom $(\mathrm{K})(0$, 2 in $4 \%$ ) na kalitev in lastnosti kalic $\mathrm{v}$ razmerah sušnega stresa (SS) $(0,-0.3,-0.6,-0.9,-1.2$ in $-1.5 \mathrm{MPa}$ vodnega potenciala). Sušni stres je zmanjšal indekse kalitve in vitalnost kalic. Največja kalitev, največja sveža in suha masa semenskih korenin (RFM in RDM) so bile dosežene pri predtretiranju semen s KNC pri -0.3 MPa SS. Povprečni čas kalitve se je v razmerah sušnega stresa povečal $\mathrm{v}$ glavnem le pri ne predtretiranih semenih. Povečanje sušnega stresa na $-1.2 \mathrm{MPa}$ je vodilo $\mathrm{k}$ zmanjšanju sveže mase semenskih korenin in poganjkov, vendar je bilo zmanjšanje pri poganjkih večje. Največji dolžini semenskih korenin in poganjkov sta bli doseženi pri predtretiranju s $4 \% \mathrm{KNC}$ in brez sušnega stresa. $\mathrm{Na}$ osnovi te raziskave lahko zaključimo, da primerno predtretiranje semen lahko poveča njihovo toleranco na sušni stress.

Ključne besede: odstotek kalitve, vitalnostni indeks, predtretiranje semen, koruza, sveža in suha masa semenskih korenin in poganjkov

\section{INTRODUCTION}

In arid and semiarid regions, drought, as an abiotic stress, is one of the major factors limiting plant growth at various stages of their life. The plant growth and development is restricted under water stress conditions so that under prolonged drought stress conditions, many plants will dehydrate and die. Water stress in plants reduces the water potential and turgor and increases concentration of solutes in cytosol. Consequently, cell enlargement, gas exchange, transpiration, plant nutrients uptake

\footnotetext{
Assistant Professor and M.Sc. student, Department of Rangeland and Watershed Management, College of Agriculture and Natural Resources, Fasa University, Fasa, IR of Iran

* Corresponding author, Email: maryamzahedifar2000@yahoo.com
} 
and transport are decreased (Lisar et al. 2012). Hegarty (1978) demonstrated that if water potential of the growth medium is reduced, due to low water availability or high soil salt concentration, germination may be delayed or prevented depending upon the extent of reduction in water potential. Osmotic solutions of poly ethylene glycol (PEG) are often used to control water potential in seed germination studies (Young et al., 1983). Mexal et al. (1975) demonstrated that PEG amendment reduces oxygen solubility and diffusivity, which have been shown to decrease as a function of PEG solution concentration. A PEGinduced reduction in oxygen availability, however, does not appear to be the limiting factor to germination response. The critical aspect of oxygen availability may simply be the distance between the seeds and the air/water interface over which oxygen would have to diffuse (Hardegree and Emmerich, 1994).

Seed germination is critical stage of plant growth which is affected by water stress. Nowadays, different methods are used to improve plant growth especially in adverse environmental conditions. One of these is seed priming which is aimed to improve seed performance under stress conditions such as salinity and drought stress (Sedghi et al., 2010). This method is defined as the uptake of water to initiate the early events of germination but not sufficient to permit seminal root protrusion, followed by drying. Application of priming increases germination rate and percentage of germination under different environmental conditions and improves seedling vigor and growth (McDonald, 2000). Bradford (1990) believed that seed priming sometimes decreases the basic water potential towards more negative values, increasing the ability of the seed to germinate under lower water availability. Activation of cell respiration and cycling, repair of macromolecules, assimilated materials translocation and weakening of seed coat structure for root emergence are reasons to increase mass of primed seeds (Bewley and Black, 1994; Osborn, 1993; Gallardo et al., 2001; Vasquez-Ramos and Sanchez, 2004 and Cantliffe et al., 1984). Four techniques are currently used to perform seed priming. These include hydropriming (soaking seeds in water and redrying them before they complete germination), osmopriming (soaking seeds in aerated osmotica of low water potential to control the amount of water absorb), matripriming (use of solid carriers with low matric potentials) and pregermination (seed hydration to the point of seminal root protrusion) (McDonald, 2000)].

Ahmed et al. (2014) indicated that with increasing drought stress, sunflower traits such as germination percentage, shoot length, germination rate and seedling fresh biomass decreased significantly; they reported the adverse effects of drought stress at $-0.12 \mathrm{MPa}$ were more drastic than $-0.06 \mathrm{MPa}$. Patane et al. (2009) illustrated that at 10 and $15^{\circ} \mathrm{C}$, germination percentage of sweet sorghum declined with decreasing water potential in comparison to control (no water stressed plants). Their results showed that in primed seeds, germination percentage were significantly higher than unprimed seeds. Furthermore, mean germination time at 15 and $35{ }^{\circ} \mathrm{C}$ increased significantly by reduced water potential. The increase of germination time was higher in unprimed seeds than in primed seeds. Jisha et al. (2013) believed that seed priming protects plants against different abiotic stresses. Finding appropriate priming agents that might be used to increase the tolerance of plants under adverse field conditions is very considerable concept for seed industry (Job et al. 2000). Adverse environmental stress such as drought, salinity and high temperature are interrelated and their detrimental effects on plants are similar. Moreover, they stimulate cell signaling pathways and cellular responses. Whereas, seed priming can put these ways in the early growth stages and result in faster plant defense responses. Potassium is one of the major plant essential nutrient elements that play key roles in the water and energy relationships of plants and can mitigate the adverse effect of drought stress on plants. The positive effect of two sources of potassium, K (nano-chelate and sulfate) on mitigating the adverse effect of salinity stress on germination and seedling characteristics of corn seeds have been shown in our previous study (Zahedifar, 2013). But from the best of our knowledge there was no published research about the effect of aforementioned $\mathrm{K}$ sources on reducing the harmful impacts of drought stress on seed germination and seedling characteristics. Therefore, the main objective of this research was to evaluate the effect of seed priming with two nano-chelate and sulfate sources of potassium $(\mathrm{K})$ on germination and seedling characteristics of corn seeds under drought stress conditions. 


\section{MATERIALS AND METHODS}

A factorial laboratory experiment of completely randomized design with three replicates was carried out to study the effect of seed priming with potassium nano-chelate and sulfate on germination and emergence traits of corn under drought stress conditions. Treatments consisted of drought stress by using poly ethylene glycol (PEG, mol wt 6000) solution, prepared as described by Michel and Kaufmann, 1973), at six osmotic potential levels of $0,-0.3,-0.6,-0.9,-1.2$ and $-1.5 \mathrm{MPa}$, two sources of potassium (K-nano-chelate including $27 \% \mathrm{~K}$ and K-sulfate) and three levels of potassium (0, 2 and $4 \%$ ) for seed priming.

Seeds of corn (Zea mays 'SC 704')) were sterilized with $5 \%$ sodium hypochlorite for three minutes then washed with distilled water. Seeds were placed in pots saturated with solutions of aforementioned K-nano-chelate and $\mathrm{K}$-sulfate for six hours. Ten seeds were placed on filter paper in glass petri dish with $9 \mathrm{~cm}$ diameter soaked with 26 $\mathrm{ml}$ solution (about of $0.4 \mathrm{~mm}$ solution in each petri dish) of desired treatment. Seed germination was recorded daily up to nine day, after the beginning of experiment (a seed was considered as germinated when its seminal root emerged by about $2 \mathrm{~mm}$ in length). Finally, seminal root and shoot lengths and their fresh mass were measured. Then seedlings' seminal roots and shoots were dried in oven for 48 hours at $72{ }^{\circ} \mathrm{C}$ and their dry masses were measured. Germination percentage (GP), germination rate (GR), mean germination time (MGT), coefficient velocity of germination $(\mathrm{CVG})$ and vigor index (VI) were calculated using Eqs. 1 to 5 (Table 1).

Table 1: Some equations for measuring the characteristics of seedlings

\begin{tabular}{|c|c|c|}
\hline No. & Equation $\dagger$ & References \\
\hline [1] & Germination Percentage $(\mathrm{GP})=\left(\frac{\text { number of normally germinated seeds }}{\text { total number of seeds }}\right) \times 100$ & (ISTA, 1996) \\
\hline [2] & Germination Rate $(\mathrm{GR})=\sum_{\mathrm{i}-1} \frac{\mathrm{n}_{i}}{\mathrm{D}_{i}}$ & $($ (IS1A, 1996) \\
\hline [3] & Mean Germination Time (MGT) $=\frac{\sum \mathrm{n} . \mathrm{d}}{\sum \mathrm{n}}$ & $\begin{array}{l}\text { (Ellis and Roberts, } \\
\text { 1981) }\end{array}$ \\
\hline [4] & Coefficent Velocity of Germination $(\mathrm{CVG})=\frac{G_{1}+G_{2}+G_{3}+\cdots+G_{n}}{\left(1 \times G_{1}\right)+\left(2 \times G_{2}\right)+\cdots+\left(n \times G_{n}\right)}$ & (Scott, et al.1984) \\
\hline [5] & Vigor Index $(\mathrm{VI})=($ Final germination percentage $\times$ seedling weight $)$ & \\
\hline
\end{tabular}

$\dagger$ Where $n_{i}$ is the number of seeds emerged on $i^{\text {th }}$ day and $D_{i}$ is the number of days counted from the beginning of the experiment. $\mathrm{J}$ is set to 9 days in this experiment, $\mathrm{n}$ is the number of seeds germinated on day and $\mathrm{d}$ is the number of days from the beginning of experiment, $\mathrm{G}_{1}-\mathrm{G}_{\mathrm{n}}$ is the number of germinated seeds from the first to the last day.

Data were analyzed statistically by application of ANOVA using MSTATC (Michigan State University, East Lansing, MI, USA) software packages and the mean values of seed traits were compared statistically using Tukey-Kramer's
Multiple Range Test at the probability level of 0.05. The Tables and Figures were prepared using Excel (Microsoft, Redmond, WA, USA) software packages.

\section{RESULTS AND DISCUSSION}

Results of variance analysis (ANOVA) for all of studied germination parameters have been summarized in Table 2. Findings indicated that effect of applied water potentials, seed priming as 
well as their interaction effects are statistically significant at the probability level of 0.01 $(\mathrm{P}<0.01)$. The results of mean comparison for studied germination attributes using TukeyKramer's Multiple Range Test at the probability level of 0.05 are described in detail as the following subsections.

\subsection{Germination percentage (GP) and germination rate (GR)}

Effect of drought stress and seed priming with potassium nano-chelate and sulfate on germination percentage of corn has been summarized in Table 3. Percentage of germinated seeds was dependent on water availability. Comparison of means showed that GP was reduced by 24 and $55 \%$ as compared to that of control at -1.2 and $-1.5 \mathrm{MPa}$ water potential $(\Psi)$, respectively. The maximum GP $(78 \%)$ was observed at water potential of 0.3 MPa. In other words, seed germination in PEG solution was not influenced by decreasing water potential less than $-0.9 \mathrm{MPa}$ (GP at this $\Psi$ was even higher than that of control). But at -0.6 and $0.9 \mathrm{MPa}$ water potential, GP was lower than that of $0.3 \mathrm{MPa}$. The GP in no primed seeds decreased significantly as the water potential decreases toward $-1.5 \mathrm{MPa}$. However, the maximum GP in no primed seeds was observed when the water potential was $-0.3 \mathrm{MPa}$. Patane et al. (2012) showed that seed germination of sweet sorghum was reduced by water stress at $\Psi<-0.6 \mathrm{MPa}$. Furthermore, they revealed that the lowering of $\Psi$ to -0.8 and $-1.0 \mathrm{MPa}$ negatively affected final germination percentage. Keshavarz et al. (2013) showed that GP of Brassica rapa L. decreased significantly with decreasing water potential (0 to 12 bar). Maraghni et al. (2010) demonstrated that seed germination of Ziziphus lotus (L.) Lam. was inhibited with increasing water stress and the highest GP were obtained under control conditions without PEG. De and Kar (1994) concluded that water absorption by seeds of mung bean is impaired, and this may result in reduced seed germination in these circumstances. It seems that followed by drought stress and reduced seed water uptake, seed physiological process decline. As a result plant nutrient availability is affected. It has been reported that drought stress reduces growth, delays maturity and reduces biomass and grain yield of corn (Cakir, 2004). Results showed that at the lowest water potential ( $\Psi=-0.3 \mathrm{MPa}$ ), GP was not only decreased but also increased by about $76 \%$ as compared to that of control. From the results, it can be concluded that the seeds of studied corn variety is not very susceptible to drought stress at the early growth stages. Chapman et al. (1997) also reported that the corn crop is particularly sensitive to drought stress several weeks before and after flowering. It should be noted that the results of our study cannot be fully discussed with respect to those obtained at mature plant and field conditions which were reported by aforementioned researchers.

Our results were also in close agreement with the findings of Saeidi et al. (2007) who reported that wheat germination percentage until water potential of $-0.8 \mathrm{MPa}$ was not changed, significantly. After that GP decreased toward -1.2 MPa. They believed that wheat is relatively resistance to drought stress at germination stage. Based on these results it may be concluded that the studied corn variety was relatively sensitive to drought stress at germination stage. Jajarmi (2012) showed that GP of wheat seeds decreased with increasing drought stress and the minimum GP was observed at $-1.2 \mathrm{Mpa}$ water potential. Karavani et al. (2013) showed that GP of Tanacetum polycephalum (L.) Schultz-Bip seeds decreased significantly with increase in severity of drought stress. They believed that moisture deficit conditions can affect enzymatic activity and consequently GP decreases under more negative osmotic potential.

Results showed that the highest mean value of GP was obtained in seeds soaked in 2 and $4 \%$ potassium nano-chelate (Table 3). Seed priming with 2 or $4 \%$ of K-nano-chelate increased the GP as compared to that of no primed seeds when seeds were not under drought stress conditions, whereas seed priming with K-sulfate decreased this trait under the aforementioned conditions, significantly. Furthermore, the GP of seeds at almost all of the applied water potential treatments was the highest when seeds were primed with 2 or $4 \% \mathrm{~K}$-nano chelate. Positive effect of seed priming on GP was only observed with potassium nano-chelate. In the other word potassium sulfate did not promote germination (increase GP). Application of 2 and $4 \%$ potassium nano-chelate increased GP by $61 \%$ as compared to that of control. Zahedifar (2013) showed that the mean value of GP in corn seeds subjected to priming with K-nano chelate was 
significantly more than that of potassium sulfate under salinity stress conditions. The reduction of GP as influenced by potassium sulfate application would be probably due to the presence of anion and cation amounts more than usual that having toxic effects on growth and decrease the water potential. As a results plant cannot absorb water. The highest GP (about $78 \%$ ) was observed in seed primed with $4 \% \mathrm{~K}$-nano chelate at $-0.3 \mathrm{MPa}$ water potential. At lower water potentials $(-1.2$ and 1.5 $\mathrm{MPa}$ ) seeds primed with potassium sulfate, failed to germinate.

Table 2: ANOVA for the effect of water stress (WS), priming (P), and their interaction effects (WS $x \mathrm{P}$ ) on the germination parameters of corn seed

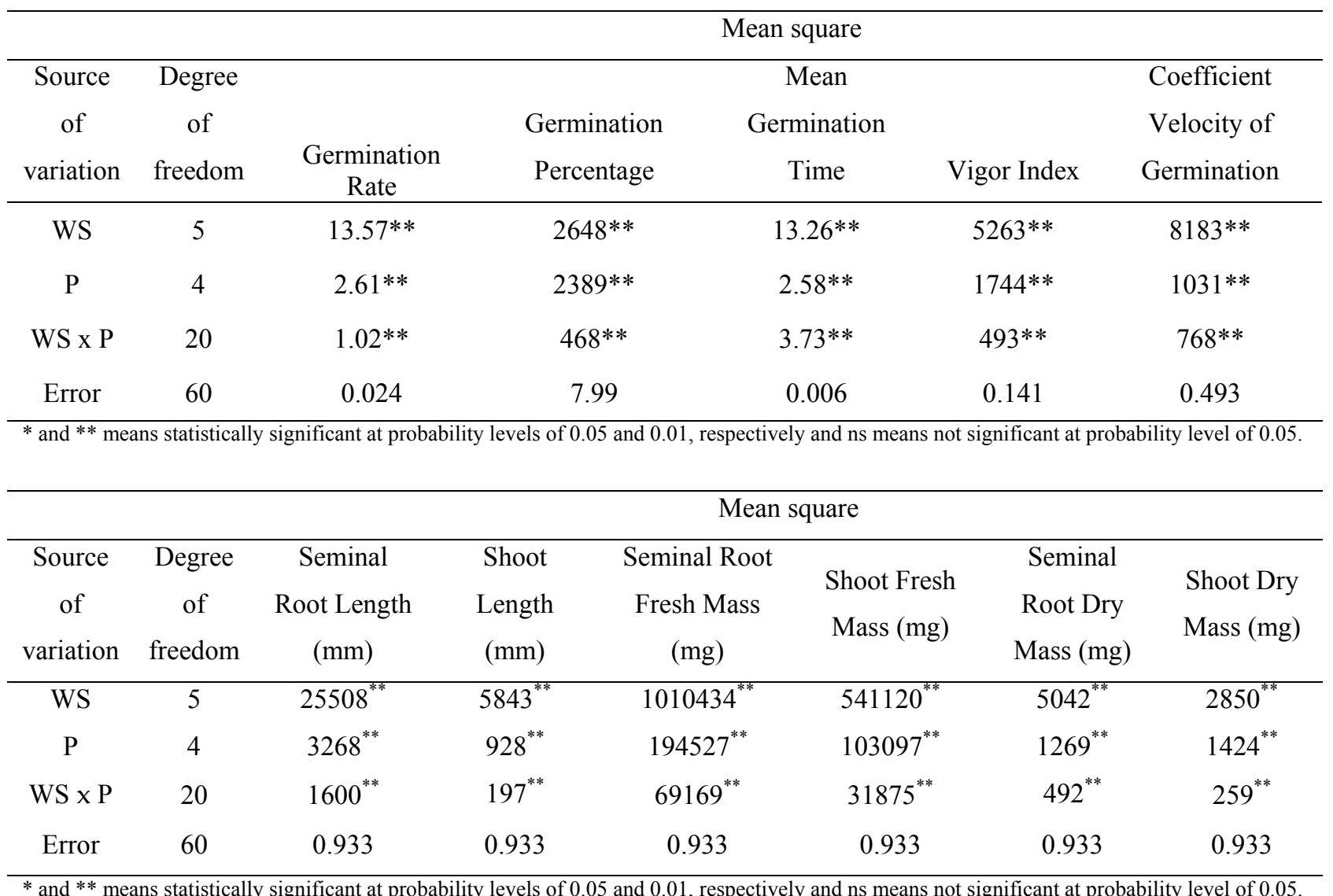


Table 3: Effect of K priming treatments and drought stress (water potential) on germination rate and percentage of corn seeds

\begin{tabular}{|c|c|c|c|c|c|c|c|}
\hline \multirow{3}{*}{$\begin{array}{c}\text { Priming } \\
\text { treatment }{ }^{\dagger} \\
(\%)\end{array}$} & \multicolumn{6}{|c|}{ Water potential $(\mathrm{MPa})$} & \multirow{3}{*}{ Mean } \\
\hline & 0 & -0.3 & -0.6 & -0.9 & -1.2 & -1.5 & \\
\hline & \multicolumn{6}{|c|}{ Germination percentage (GP) } & \\
\hline 0 & $33 \mathrm{e}^{t+}$ & $44 \mathrm{~d}$ & $23 \mathrm{f}$ & $22 \mathrm{f}$ & $22 \mathrm{f}$ & $22 \mathrm{f}$ & $28 \mathrm{~B}$ \\
\hline NK2 & $34 \mathrm{e}$ & $67 \mathrm{~b}$ & $56 \mathrm{c}$ & $33 \mathrm{e}$ & $56 \mathrm{c}$ & $11 \mathrm{~g}$ & $43 \mathrm{~A}$ \\
\hline NK4 & $33 \mathrm{e}$ & $78 \mathrm{a}$ & $56 \mathrm{c}$ & $56 \mathrm{c}$ & $11 \mathrm{~g}$ & $33 \mathrm{e}$ & $45 \mathrm{~A}$ \\
\hline SK2 & $22 \mathrm{f}$ & $22 \mathrm{f}$ & $43 d$ & $22 \mathrm{f}$ & $11 \mathrm{~g}$ & 0 & $20 \mathrm{D}$ \\
\hline SK4 & $22 \mathrm{f}$ & $44 \mathrm{~d}$ & $22 \mathrm{f}$ & 33 e & $11 \mathrm{~g}$ & 0 & $22 \mathrm{C}$ \\
\hline \multicolumn{8}{|c|}{ Germination rate (GR) } \\
\hline 0 & $3.00 \mathrm{~b}$ & $2.62 \mathrm{c}$ & $0.83 \mathrm{ghi}$ & $0.41 \mathrm{klm}$ & $1.00 \mathrm{gh}$ & $0.52 \mathrm{jkl}$ & $1.39 \mathrm{~B}$ \\
\hline NK2 & $2.51 \mathrm{c}$ & $3.94 \mathrm{a}$ & $1.46 \mathrm{ef}$ & $0.91 \mathrm{ghi}$ & $1.37 \mathrm{f}$ & $0.20 \mathrm{mn}$ & $1.73 \mathrm{~A}$ \\
\hline NK4 & $2.99 \mathrm{~b}$ & $2.94 \mathrm{~b}$ & $1.66 \mathrm{e}$ & 1.39 ef & $0.20 \mathrm{mn}$ & 0.78 hij & $1.66 \mathrm{~A}$ \\
\hline SK2 & $0.66 \mathrm{ijk}$ & $1.50 \mathrm{ef}$ & $2.12 \mathrm{~d}$ & $0.25 \mathrm{lmn}$ & $0.21 \mathrm{mn}$ & 0 & $0.79 \mathrm{D}$ \\
\hline SK4 & $2.00 \mathrm{~d}$ & $2.58 \mathrm{c}$ & $1.01 \mathrm{gh}$ & $1.08 \mathrm{~g}$ & $0.50 \mathrm{kl}$ & 0 & $1.19 \mathrm{C}$ \\
\hline Mean & $2.23 \mathrm{~B}$ & $2.72 \mathrm{~A}$ & $1.42 \mathrm{C}$ & $0.81 \mathrm{D}$ & $0.65 \mathrm{E}$ & $0.30 \mathrm{~F}$ & \\
\hline
\end{tabular}

Effect of drought stress and seed priming with potassium nano-chelate and sulfate on germination rate (GR) of corn has been summarized in Table 3. Results showed that the maximum mean value of GR over the studied priming treatments was obtained at $-0.3 \mathrm{MPa}$ water potential. However, the maximum GR value of unprimed seeds was obtained at normal conditions (without any water stress, $\Psi=0 \mathrm{MPa}$ ). In no primed seeds, the GR values decreased significantly with increasing the degree of applied water stress conditions (from 0 to $-1.5 \mathrm{MPa}$ ). In general, imposition of drought stress except -0.3 MPa resulted in a significant decreases in the mean value of seed germination rate (GR) over all of applied priming treatments, also the highest decline about $86 \%$ as compared to that of control in GR occurred at the highest drought stress (water potential of $-1.5 \mathrm{MPa}$ ). Gill et al. (2003) demonstrated that application of strong water or salt stresses in sorghum increased suger levels of embryos. This helps in osmoregulation under stress conditions. Our results are in close agreement with the findings of Jajarmi (2012) who reported that GR of wheat declined significantly with the decrease in water potential ( $\Psi<$ $0.3 \mathrm{MPa}$ ). According to the finding of Keshavrz Afshar et al. (2012), the minimum GR was obtained at $-1.2 \mathrm{MPa}$ water potential. Saedi et al. (2007) showed that GR of different wheat genotypes against the applied osmotic potential, were not similar. They reported at first level of applied osmotic stress (-0.4 MPa), germination rate of the most studied genotypes was induced and after that declined in more negative potential.

Findings indicated that when seeds are in normal conditions (without drought stress) application of all priming treatments, K-nano-chelate or sulfate, decreased GR value significantly as compared to that of control (except for $4 \% \mathrm{~K}$-nano chelate that had no significant effect). Our results also showed that the highest mean value of GR was obtained in seeds soaked in 2 and $4 \%$ potassium nano-chelate. Whereas, seed priming with potassium sulfate decreased the mean value of GR by about of 24 and $19 \%$ as compared to that of control, significantly probably due to the toxic effect of cation and anion. Patane et al. (2009) showed that seed priming of sorghum with PEG increased germination and shortened the delay in germination time due to the increase in saline stress. They believed that in primed seeds, water absorption were faster than unprimed, irrespective of salt concentration of the solution. According to 
McDonald (2000), primed seeds obtain the potential to rapidly absorb and revive the seed metabolism thus improving the germination rate. Bradford (1990) demonstrated that seed priming increased seed germination under low water availability due to avoid more negative water potential. Our results revealed that the maximum GR was observed at $-0.3 \mathrm{MPa}$ water potential with application of $2 \%$ potassium nano-chelate. Our findings revealed that the reduction in GR because of drought stress, decreased as seed primed with 2 and $4 \% \mathrm{k}$-nano-chelate, except at $-1.5 \mathrm{MPa}$.

\subsection{Mean germination time (MGT) and coefficient velocity of germination (CVG)}

The effects of corn seed priming with K-nano chelate and sulfate under drought stress on MGT have been shown in Table 4. The MGT values of non-primed seeds increased significantly from 1 to 4.67 as the severity of drought stress conditions increased (the applied water potential decreased from 0 to $-1.5 \mathrm{MPa}$ ). Results showed that the mean value of MGT at $-1.5 \mathrm{MPa}$ water potential was 4.67 fold higher than control. In fact, drought stress increased the mean value of MGT and the highest MGT was obtained when water potential decreased to $-1.5 \mathrm{MPa}$. Findings indicated that when seeds were under normal condition (without waters tress condition), application of K-nanochelate for priming decreased the MGT values, significantly as compared to that of control (nonprimed seeds), but seed priming with K-sulfate increased it, significantly. In addition, MGT of primed and non-primed seeds increased under drought stress but the effect of drought stress on MGT of primed seeds was smaller than that of noprimed seeds. Indeed, the mean value of MGT in seeds subjected to priming with $2 \% \mathrm{~K}$-nano chelate was the lowest in comparison to that of other levels of potassium nano chelate or sulfate. The same results were also reported by Zahedifar (2013) for corn seeds but under salinity stress conditions. Patane et al. (2009) showed that germination time of sorghum increased by increasing salinity stress, but this germination time in PEG primed seeds was lower than that of unprimed seeds at 10 and $15^{\circ} \mathrm{C}$. Moradi et al. (2012) showed that hydro and osmo priming of tall wheat grass decreased MGT. In this case, priming with urea and distilled water has more reducing effect on MGT as compared to that of PEG. Elouaer and Hannachi (2012) reported that MGT of safflower seeds increased by salinity stress for both of primed and non-primed seeds.

Table 4 highlights the effect of drought stress and potassium priming as nano-chelate and sulfate on CVG of corn. The CVG values of non-primed seeds decreased significantly from 45 to 20 as the severity of drought stress conditions increased (the applied water potential decreased from 0 to 1.5 MPa). Results also showed that with increasing drought stress the mean CVG values decreased significantly, so that the maximum and minimum CVG values (54.5 and 21 germinated seeds day ${ }^{-1}$, respectively) of corn seeds were obtained at control and -1.2 MPa water potential, respectively. Our results were in close agreement with the findings of Masarat et al. (2014) who reported that the highest CVG value of corn seeds was obtained for control and increasing osmotic potential from $\Psi$ of 0 to $-1.2 \mathrm{MPa}$, declined CVG significantly. Jajarmi (2012) showed that CVG of wheat decreased significantly when drought stress increased from 0 to $-1.2 \mathrm{MPa}$ (19.39 and 11.90 germination seeds per day respectively); although it was not significant difference between control and $-0.3 \mathrm{MPa}$ drought level.

Findings indicated that when seeds were under normal condition (without waters tress condition), application of K-nano-chelate for priming increased the MGT values, significantly as compared to that of control (non-primed seeds), but seed priming with K-sulfate decreased it (for $2 \% \mathrm{~K}$-sulfate) or did not change it (for $4 \% \mathrm{~K}$ sulfate), significantly. Findings also revealed that the mean CVG values of primed seeds were higher than unprimed seeds. Furthermore, this positive effect was sharper at low applied level of potassium nano-chelate i. e. $2 \%$. It was $39.5 \%$ more than control. The highest CVG (about 75) was observed in seeds primed with $2 \% \mathrm{~K}$-nano chelate without any drought stress. Elouaer and Hannachi (2012) illustrated that CVG of safflower in $\mathrm{NaCl}$ seed priming was higher than control seeds. 
Table 4: Effect of $\mathrm{K}$ priming treatments and drought stress (water potential) on mean germination time (day) and coefficient velocity germination of corn seeds

\begin{tabular}{|c|c|c|c|c|c|c|c|}
\hline \multirow{3}{*}{$\begin{array}{c}\text { Priming } \\
\text { treatment } \\
+(\%)\end{array}$} & \multicolumn{6}{|c|}{ Water potential $(\mathrm{MPa})$} & \multirow[t]{3}{*}{ Mean } \\
\hline & 0 & -0.3 & -0.6 & -0.9 & -1.2 & -1.5 & \\
\hline & \multicolumn{6}{|c|}{ Mean Germination Time (MGT) } & \\
\hline 0 & $1.00 \mathrm{n}^{\dagger \dagger}$ & $2.16 \mathrm{j}$ & $3.01 \mathrm{~g}$ & $3.32 \mathrm{f}$ & $4.01 \mathrm{~d}$ & $4.67 \mathrm{a}$ & $3.03 \mathrm{~A}$ \\
\hline NK2 & 0.83 o & $1.78 \mathrm{kl}$ & $2.50 \mathrm{~h}$ & $2.16 \mathrm{i}$ & $3.50 \mathrm{e}$ & $3.33 \mathrm{f}$ & $2.35 \mathrm{C}$ \\
\hline NK4 & $0.67 \mathrm{p}$ & $2.05 \mathrm{ij}$ & $3.58 \mathrm{e}$ & $4.16 \mathrm{c}$ & $3.67 \mathrm{e}$ & $3.33 \mathrm{f}$ & $2.91 \mathrm{~B}$ \\
\hline SK2 & $2.00 \mathrm{j}$ & $1.33 \mathrm{~m}$ & $3.50 \mathrm{e}$ & $4.33 \mathrm{~b}$ & $3.67 \mathrm{e}$ & 0 & $2.96 \mathrm{~B}$ \\
\hline SK4 & $1.85 \mathrm{k}$ & $1.33 \mathrm{~m}$ & $3.45 \mathrm{ef}$ & $3.50 \mathrm{e}$ & $4.00 \mathrm{~d}$ & 0 & $2.82 \mathrm{~B}$ \\
\hline Mean & $1.27 \mathrm{~F}$ & $1.73 \mathrm{E}$ & $3.21 \mathrm{C}$ & $3.49 \mathrm{~B}$ & $3.77 \mathrm{~A}$ & $3.77 \mathrm{~A}$ & \\
\hline \multicolumn{8}{|c|}{ Coefficient velocity of germination (CVG) } \\
\hline 0 & $45.0 \mathrm{~d}$ & $33.3 \mathrm{f}$ & $27.8 \mathrm{~g}$ & $20.0 \mathrm{~h}$ & $20.0 \mathrm{~h}$ & $20.0 \mathrm{~h}$ & $27.7 \mathrm{C}$ \\
\hline NK2 & $75.0 \mathrm{a}$ & 42.9 de & $38.8 \mathrm{e}$ & $30.0 \mathrm{fg}$ & $25.0 \mathrm{gh}$ & $25.0 \mathrm{gh}$ & $38.6 \mathrm{~A}$ \\
\hline NK4 & $67.0 \mathrm{~b}$ & $28.0 \mathrm{~g}$ & $31.3 \mathrm{fg}$ & $22.7 \mathrm{~h}$ & $20.0 \mathrm{~h}$ & $25.0 \mathrm{gh}$ & $32.3 \mathrm{~B}$ \\
\hline SK2 & $33.3 \mathrm{f}$ & $55.7 \mathrm{c}$ & $30.8 \mathrm{fg}$ & $25.5 \mathrm{gh}$ & $20.0 \mathrm{~h}$ & 0 & $33.1 \mathrm{~B}$ \\
\hline SK4 & $52.0 \mathrm{~cd}$ & $44.4 \mathrm{~d}$ & 35.0 ef & $33.3 \mathrm{f}$ & $20.0 \mathrm{~h}$ & 0 & $34.7 \mathrm{~B}$ \\
\hline Mean & $54.46 \mathrm{~A}$ & $40.86 \mathrm{~B}$ & $32.75 \mathrm{C}$ & $24.10 \mathrm{D}$ & $21.00 \mathrm{E}$ & $23.33 \mathrm{E}$ & \\
\hline
\end{tabular}

$\uparrow$ Treatments consisted of 0: control, NK2: $2 \%$ potassium-nano-chelate, NK4: $4 \%$ potassium-nano-chelate, SK2: $2 \%$ potassium sulfate and SK $4: 4 \%$ potassium sulfate.

it Means in each row or column followed by the same lowercase or capital letters are not significantly different $(p<0.05)$ by Tukey-Kramer's Multiple Range Test.

\subsection{Seminal root fresh mass (RFM) and seminal root dry mass (RDM)}

Table 5 shows the effect of drought stress and seed priming with $\mathrm{K}$ treatments on RFM of corn. Results showed that increasing drought stress from $\Psi$ of -0.3 to $-1.2 \mathrm{MPa}$ led to significant decrease in RFM of non-primed seeds. Also the same trend was obtained for the mean value of RFM over all of primed and non-primed seeds. The maximum and minimum mean value of PFM were obtained at $\Psi$ of -0.3 and $-1.5 \mathrm{MPa}$. Our findings showed that the mean value of RFM decreased significantly by about of $49,58,77$ and $93 \%$ compared to that of control at drought levels of $-0.6,-0.9,-1.2$ and 1.5 $\mathrm{MPa}$. Whereas, at $-0.3 \mathrm{MPa}$ drought level, RFM increased about $93 \%$ compared to that of control. Khakshoor et al. (2011) reported that drought stress decreased RFM of Anethum graveolens L. significantly (about $65.1 \%$ ). The reduction in fresh plant mass might be associated with declined cell growth and enlargement due to the low turgor pressure under drought stress (Rane et al., 2001). Primed seed showed better performance than non-primed seeds (Table 5).

As results indicated the RFM values of seeds at normal conditions (without water stress) subjected to priming with the high level $(4 \%)$ of $\mathrm{K}$ - nanochelate or sulfate were significantly more those of control or those of seeds primed with low level $(2 \%)$ of K- nano-chelate or sulfate. Furthermore, the mean value of RFM in seeds subjected to priming with $4 \% \mathrm{~K}$-nano chelate was significantly more than that of seed priming with potassium sulfate. Furthermore, the highest levels of applied $\mathrm{K}$ were more effective than the lower levels. The highest RFM (about $1080 \mathrm{mg}$ ) was observed in seeds primed with $4 \% \mathrm{~K}$-nano chelate at $-0.3 \mathrm{MPa}$ water potential, whereas, the lowest RFM (about $10 \mathrm{mg}$ ) was observed with application of -1.2 and $1.5 \mathrm{MPa}$ water potential without priming. Results showed that the reduction of RFM in seeds primed with K-nano chelate and potassium sulfate at the high level of applied drought stress (-1.2 $\mathrm{MPa}$ ) was lower than that of seeds without any priming treatment. 
Table 5: Effect of $\mathrm{K}$ priming treatments and drought stress (water potential) on seminal root fresh and dry mass (mg) of corn seed

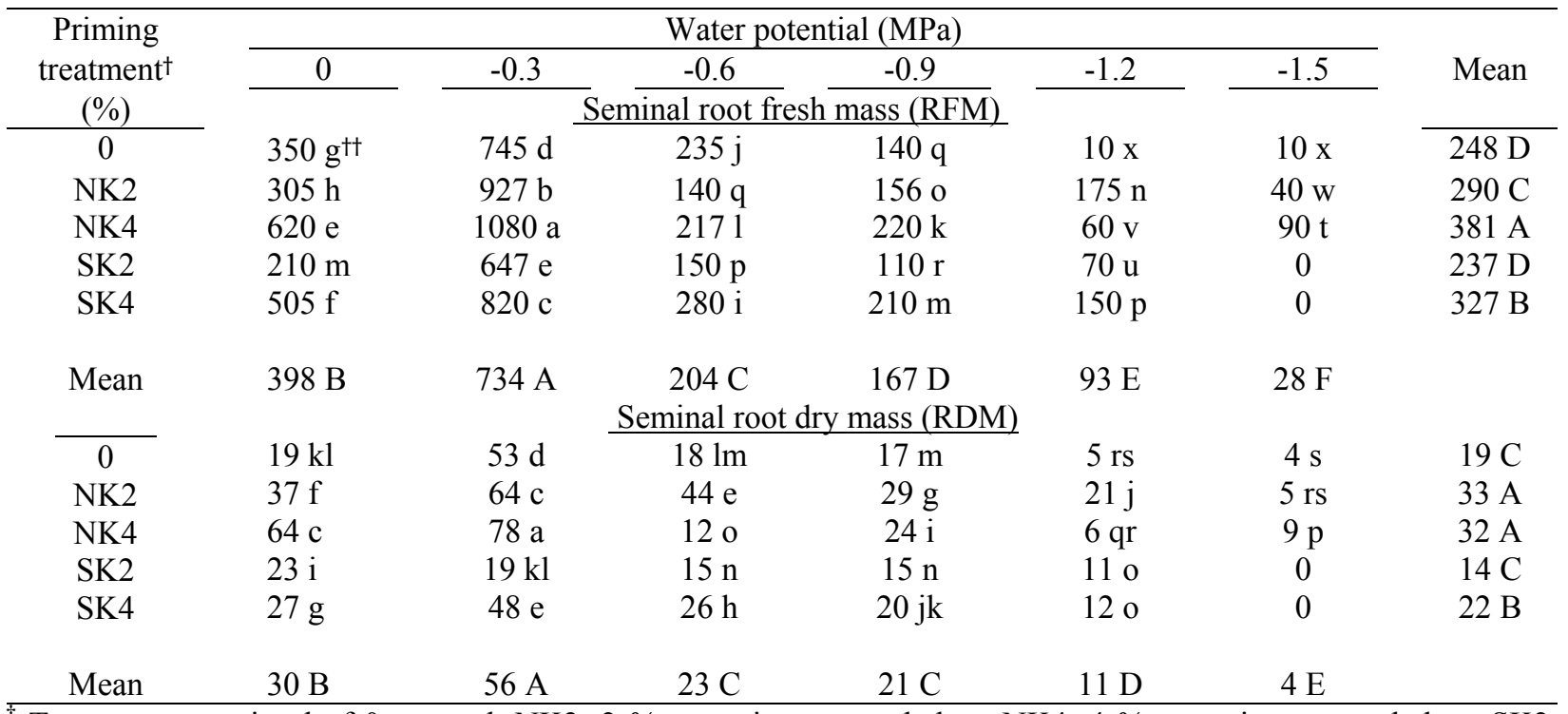

Treatments consisted of 0: control, NK2: $2 \%$ potassium-nano-chelate, NK4: $4 \%$ potassium-nano-chelate, SK2: $2 \%$ potassium sulfate and SK $4: 4 \%$ potassium sulfate.

i† Means in each row or column followed by the same lowercase or capital letters are not significantly different $(p<0.05)$ by Tukey-Kramer's Multiple Range Test.

Findings revealed that increasing drought stress from $\Psi$ of -0.3 to $-1.2 \mathrm{MPa}$ led to significant decrease in RDM of non-primed seeds. Also the same trend was obtained for the mean value of $\mathrm{RDM}$ over all of primed and non-primed seeds. Application of drought stress at $-0.6,-0.9,-1.2$ and $-1.5 \mathrm{MPa}$ water potential, decreased the mean RDM values by about 23, 30, 63 and $87 \%$ compared to that of control. Khakshoor et al. (2011) showed that RDM of Anethum graveolens L. decreased, significantly with decreasing water potential. Soltani and Galeshi (2002) believed that wheat seedling mass loss is due to decline of storage material in seeds and transfer them from cotyledons to embryonic axis. Saedi et al. (2007) reported that in some of wheat cultivars RDM increased with decreasing osmotic potential to $0.4 \mathrm{MPa}$ afterward decreased. The RDM values of seeds at normal conditions (without water stress) subjected to priming with both of $\mathrm{K}$ sources were significantly higher than that of control. Furthermore, findings indicated that seed priming with K-nano chelate increased RDM, significantly as compared to that of control by about $63 \%$. The highest RDM was observed in seed primed with $4 \% \mathrm{~K}$-nano chelate at drought stress level of -
$0.3 \mathrm{MPa}$. Massarat et al. (2014) illustrated that seed priming of maize with distilled water and $1 \%$ $\mathrm{KNO}_{3}$ increased RDM significantly as compared to that of control.

\subsection{Shoot fresh mass (SFM) and shoot dry mass (SDM)}

Table 6 shows the effect of drought stress and seed priming with $\mathrm{K}$ treatments on SFM of corn. Results showed that increasing drought stress from $\Psi$ of 0 to $1.2 \mathrm{MPa}$ resulted in significant decreases in SFM of non-primed seeds. Also the same trend was obtained for the mean value of SFM over all of primed and non-primed seeds. So that, the mean value of SFM decreased significantly by about of $27,60,77,92$ and $97 \%$ as compared to that of control at $\Psi$ of $-0.3,-0.6,-0.9,-1.2$ and $-1.5 \mathrm{MPa}$, respectively. Results showed that the influence of drought stress on SFM was more severe than on seminal root. Our results were in close agreement with the findings of some investigators like Keshavarz et al. (2013) who believed that at low drought stress, growth of root and shoot may stimulate. 
Table 6: Effect of $\mathrm{K}$ priming treatments and drought stress (water potential) on shoot fresh and dry mass (mg) of corn seeds

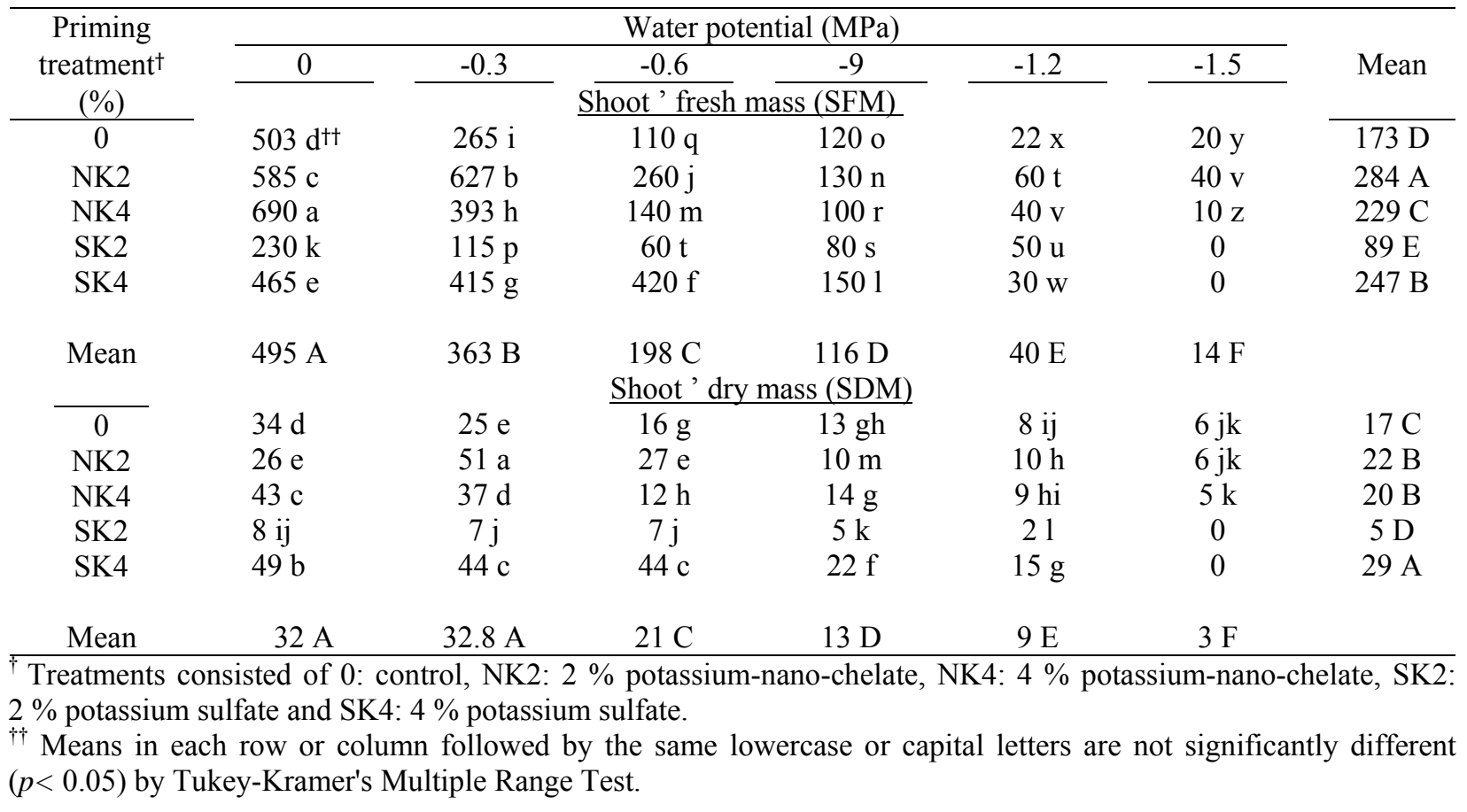

It has been reported that under drought stress conditions fresh mass of wheat (Range et al. 2001) and pearl millet (Kusaka et al. 2005) decreased. Sankar et al. (2007) showed that reduction of fresh mass under drought stress conditions might be due to the suppression of cell expansion and cell growth resulted from the low turgor pressure.

The SFM values of seeds at normal conditions (without water stress) subjected to priming with Knano-chelate were significantly higher than that of control. But, seed priming with K-sulfate decreased SFM of non-water-stressed seeds as compared to that of control (non-primed seeds), significantly. However, results indicated that priming of seeds with 2 and $4 \% \mathrm{~K}$-nano chelate and $4 \%$ potassium sulfate increased the mean value of SFM, significantly by about of 64, 32 and $43 \%$ as compared to that of control, respectively. The highest SFM (690 mg) was obtained in seeds subjected to priming with $4 \% \mathrm{~K}$-nano chelate without drought stress, whereas, the lowest SFM (10 mg) was observed in seeds primed with $4 \% \mathrm{~K}$ nano chelate at $-1.5 \mathrm{MPa}$ water potential. Hopper et al. (1979) illustrated that seeds priming increases water absorption from growth medium, for this reason metabolic activity in seed during germination process begins much earlier than seminal root and shoot appearance. Masarat et al. (2014) reported that seed soaking of corn with distilled water and $1 \% \mathrm{KNO}_{3}$ increased SFM significantly by about 26 and $21 \%$, respectively as compared to that of control.

Similar to those obtained for SFM, results showed that increasing drought stress from $\Psi$ of 0 to 1.2 $\mathrm{MPa}$ resulted in significant decreases in SDM of non-primed seeds. Also the relatively same trend was obtained for the mean value of SDM over all of primed and non-primed seeds. In other words, results indicated that SDW decreased, significantly with reduction of water potential from -0.3 to $-1.5 \mathrm{MPa}$. These reductions were $34,59,72$ and $91 \%$ as compared to that of control when seeds subjected to water potential of $-0.6,-0.9,-1.2$ and $-1.5 \mathrm{MPa}$, respectively. Decreased plant biomass has been also reported by Pan et al. (2003) and Rodriguez et al. (2005) for wheat and Pallenis maritime (L.) Greuter, respectively. Bhatt and Srinivasarao (2005) reported that the reduction of dry mass may be due to the considerable decrease in plant growth, photosynthesis and canopy structure as indicated by leaf senescence during drought stress in Abelmoschus esculentum L. 
The SDM values of seeds at normal conditions (without water stress) subjected to priming with high $(4 \%)$ levels of K-nano-chelate or K-sulfate were significantly higher than that of control or those of seeds primed with low level $(2 \%)$ of $\mathrm{K}$. However, results indicated that that seed priming led to significant increase in the mean value of SDM as compared to that of control (except for $2 \% \mathrm{~K}$-sulfate). Our findings indicated that the adverse effect of drought stress on SDM of primed seed with the high level (4\%) of K-nano chelate and sulfate was less than that of non-primed seeds. The highest SDM was observed in seed primed with $2 \%$ K-nano chelate at $-0.3 \mathrm{MPa}$ water potential. Similar results were found by Sivritepe et al. (1997) who reported an increase in melons seedling dry mass for seeds primed with $\mathrm{NaCl}$. Elouaer and Hannachi (2012) revealed that reduction in germination parameters and seedling growth was more profound in unprimed seeds than that of primed seeds of safflower.

\subsection{Shoot length (SL)}

The effect of drought stress and seed priming with K-nano chelate and sulfate on SL of corn has been shown in Figure 1. Similar to those obtained for SFM and SDM, results indicated that increasing drought stress from $\Psi$ of 0 to $-1.2 \mathrm{MPa}$ resulted in significant decreases in SL of non-primed seeds. In other words, results indicated that drought stress has significant inhibitory effect on SL. The shoot length of seedling decreased significantly by 15 , $33,62,85$ and $95 \%$ at applied water potential of $0.3,-0.6,-0.9,-1.2$ and $-1.5 \mathrm{MPa}$, respectively. Ebadi et al. (2011) reported that the shoot length of
Matricaria recutita L. was 6.94 and $2.58 \mathrm{~cm}$ in control and water potential of $-0.6 \mathrm{Mpa}$, respectively. They also showed that at the lowest applied water potential germination did not occur.

Results indicated that the SL of germinated seeds at normal conditions (without water stress) increased significantly when seeds subjected to priming with K-nano-chelate. But, seed priming with K-sulfate had no significant effect on SL of germinated seeds as compared to that of control. Furthermore, findings revealed that seed priming with the highest level (4\%) of K-nano chelate and $\mathrm{K}$-sulfate increased the mean values of SL over all of applied water potentials, significantly as compared to that of control. The highest shoot length was observed with application of $4 \% \mathrm{~K}$ nano chelate without any drought stress.

\subsection{Seminal root length (SRL)}

Results indicated the SRL of non-primed germinated seeds increased when low level of drought stress ( $\Psi$ of 0 to $-0.9 \mathrm{MPa}$ ) were applied, whereas, applying high level of drought stress ( $\Psi$ of -1.2 and $-1.5 \mathrm{MPa}$ ) decreased it significantly. However, the slightly different trend was obtained for the mean value of SRL. So that, applying water potential of $-0.6,-0.9,-1.2$ and $-1.5 \mathrm{MPa}$ decreased SRL, significantly by about of $33,57,81$ and $91 \%$ as compared to that of control, respectively (Figure 2). Khakshoor Moghadam et al. (2011) reported that with increasing drought stress from $-0.4 \mathrm{MPa}$, SRL of Anethum gravoelens L. declined, significantly. 




Figure 1: Effect of water potential (drought stress) and seed priming with potassium on shoot length of corn as compared to that of control, 0K, 0WP.Treatments consisted of drought stress (0WP, 0.3WP, 0.6WP, 0.9WP, 1.2WP and 1.5WP, shows drought stress of $0,0.3,0.6,0.9,1.2$ and $1.5 \mathrm{MPa}$, respectively), potassium nanochelate $(0 \mathrm{~K}, 2 \mathrm{KN}$ and $4 \mathrm{KN}$ shows seed priming with 0,2 and $4 \%$ of $\mathrm{K}$-nano chelate) and potassium sulfate $(0 \mathrm{~K}$, $2 \mathrm{KS}$, and $4 \mathrm{KS}$ shows seed priming with 0,2 and $4 \%$ of $\mathrm{K}$ sulfate, respectively). Columns by the same lower letters are not statistically different at the probability level of 0.05 by Tukey-Kramer's Multiple Range Test.

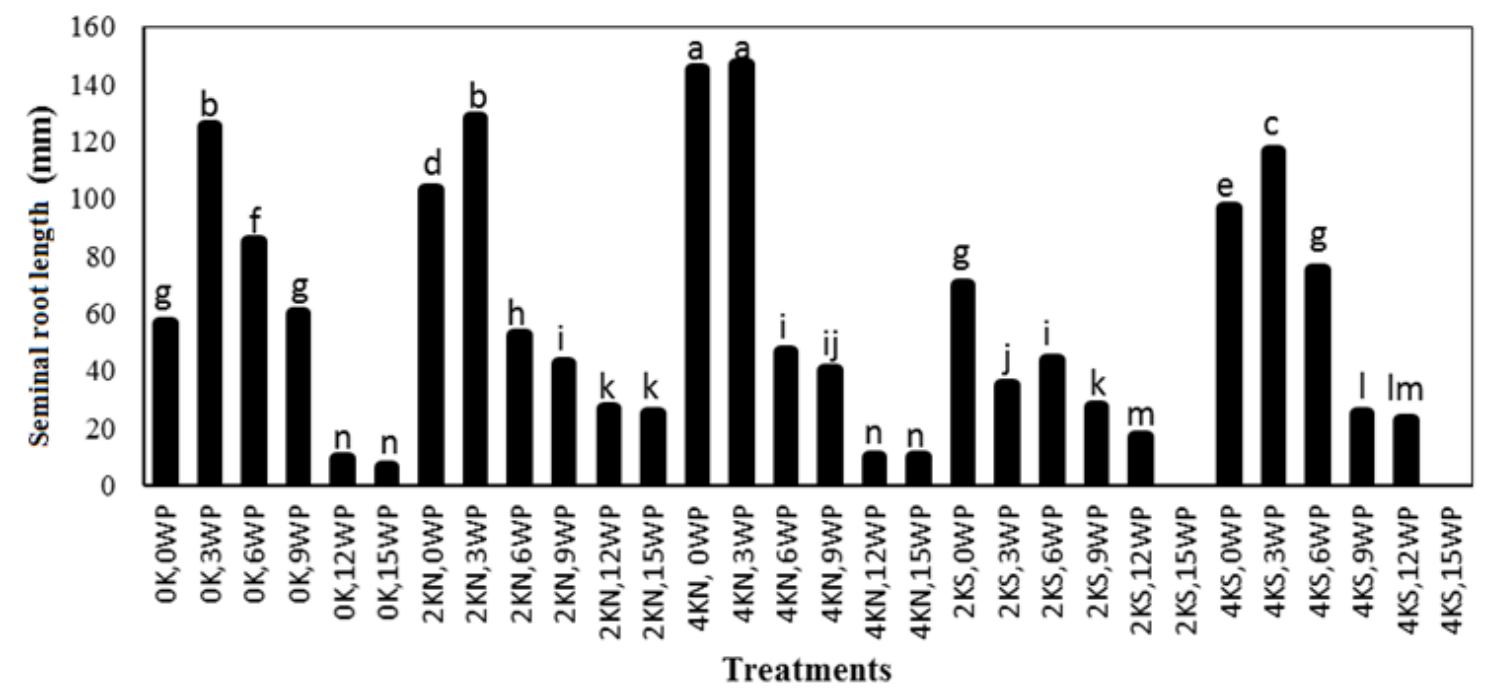

Figure 2: Effect of water potential (drought stress) and seed priming with potassium on seminal root length of corn as compared to that of control, $0 \mathrm{~K}, 0 \mathrm{WP}$.Treatments consisted of drought stress (0WP, 0.3WP, 0.6WP, 0.9WP, 1.2WP and 1.5WP, shows drought stress of $0,0.3,0.6,0.9,1.2$ and $1.5 \mathrm{MPa}$, respectively), potassium nanochelate $(0 \mathrm{~K}, 2 \mathrm{KN}$ and $4 \mathrm{KN}$ shows seed priming with 0,2 and $4 \%$ of $\mathrm{K}$-nano chelate) and potassium sulfate $(0 \mathrm{~K}$, $2 \mathrm{KS}$, and $4 \mathrm{KS}$ shows seed priming with 0,2 and $4 \%$ of $\mathrm{K}$ sulfate, respectively). Columns by the same lower letters are not statistically different at the probability level of 0.05 by Tukey-Kramer's Multiple Range Test.

Results revealed that the SRL of germinated seeds at normal conditions (without water stress) increased significantly when seeds subjected to priming with K-nano-chelate or K-sulfate. Furthermore, findings indicated that seed priming with K-nano chelate and sulfate, increased the mean value of SRL over all of applied water potentials, significantly; whereas, high level of applied potassium sulfate $(4 \%)$ was not effective. The maximum value of SRL was observed in seeds primed with $4 \% \mathrm{~K}$-nano chelate without drought stress and at the lowest level of applied water potential (-0.3 MPa). Farooq et al. (2005) believed that seed priming due to earlier germination, resulted in drastic seedlings with more root and shoot length than that of the seedling of un-primed 
seeds. Our results are in accordance to the finding of Basra et al. (2003) who reported that wheat shoot and root length increased in hydro-primed and matric-conditioned seeds for 12 or $24 \mathrm{~h}$. This effect might be due to the higher embryo-cell wall extensibility.

\subsection{Vigor index (VI)}

Findings revealed that increasing drought stress from $\Psi$ of -0.3 to $-1.2 \mathrm{MPa}$ led to significant decrease in VI of non-primed seeds. Also the same trend was obtained for the mean value of VI over all of primed and non-primed seeds. So that increasing drought stress from -0.3 to $-1.5 \mathrm{MPa}$ causes a significant decrease in VI of seeds (Figure 3 ). Results indicated that VI of seedling decreased significantly by $8,37,72$ and $91 \%$ in response to applied water potentials of $-0.6,-0.9,-1.2$ and -1.5 $\mathrm{MPa}$, respectively. Van Gastel et al. (1996) illustrated that reduction of seed VI is probably due to decreasing water availability, which changes enzyme activity by inducing some problems in the transfer from endosperm reserves for the growth of embryonic axes and synthesis compounds of seed. Organ growth also depends on the speed of producing new cells and rapidly growing cells that is negatively influenced by drought stress. Both of processes are sensitive to cell swelling, but the sensitivity probably depends on tissue, species or stress intensity. So that when the seeds are exposed to drought, flexibility decreased in cells wall growing, that reduces cell expansion and consequently organs growth (Natale et al. 2010).

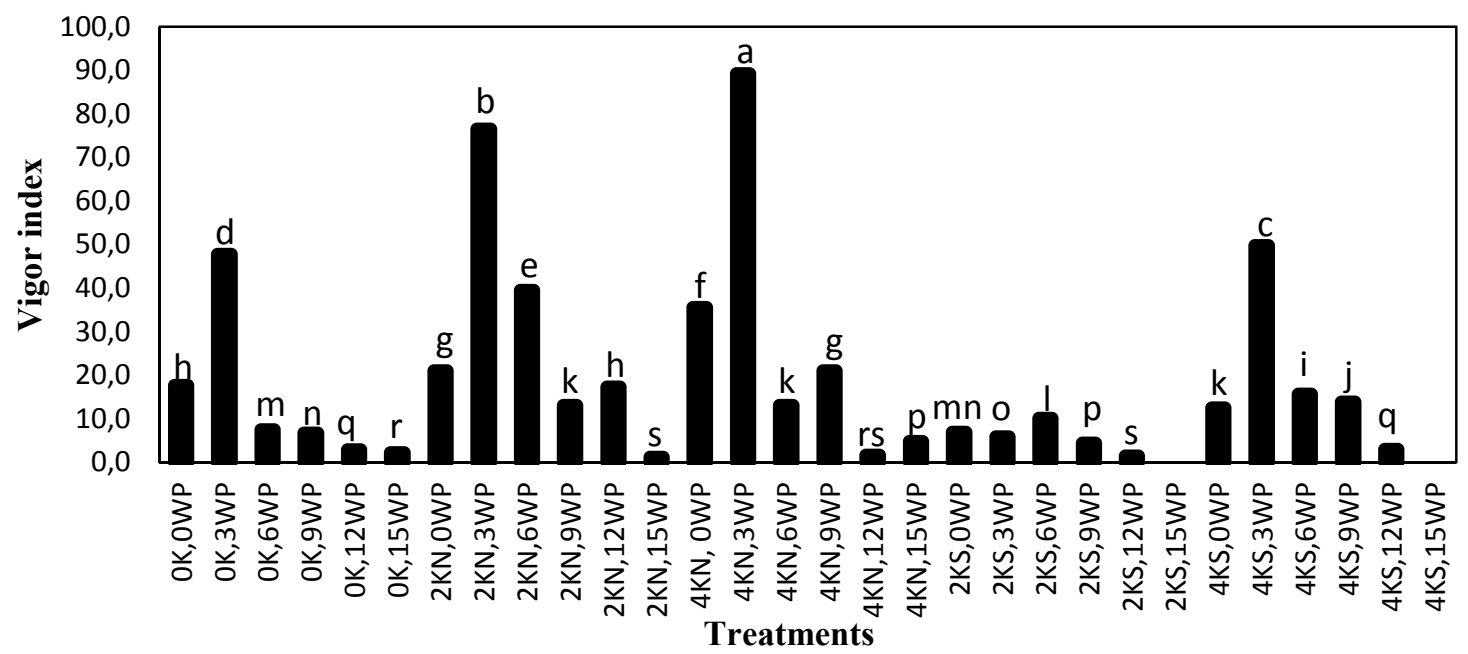

Figure 3: Effect of water potential (drought stress) and seed priming with potassium on vigor index of corn as compared to that of control, $0 \mathrm{~K}, 0 \mathrm{WP}$. Treatments consisted of drought stress (0WP, 0.3WP, 0.6WP, 0.9WP, 1.2WP and 1.5WP, shows drought stress of $0,0.3,0.6,0.9,1.2$ and $1.5 \mathrm{MPa}$, respectively), potassium nanochelate $(0 \mathrm{~K}, 2 \mathrm{KN}$ and $4 \mathrm{KN}$ shows seed priming with 0,2 and $4 \%$ of $\mathrm{K}$-nano chelate) and potassium sulfate ( $0 \mathrm{~K}$, $2 \mathrm{KS}$, and $4 \mathrm{KS}$ shows seed priming with 0,2 and $4 \%$ of $\mathrm{K}$ sulfate, respectively). Columns by the same lower letters are not statistically different at the probability level of 0.05 by Tukey-Kramer's Multiple Range Test.

The VI of germinated seeds at normal conditions (without water stress) increased significantly when seeds subjected to priming with K-nano-chelate, whereas this trait decreased significantly when subjected to priming with K- sulfate. Furthermore, our findings revealed that seed priming with the highest $(4 \%)$ level of K-nano chelate and Ksulfate increase the mean value of VI significantly compared to that of control. The maximum value of VI was observed with application of $4 \% \mathrm{~K}$ - nano chelate at $-0.3 \mathrm{MPa}$ water potential. These observations are in accordance to the findings of Elouaer and Hannachi (2012) for safflower seeds. Their results showed that seed priming with $\mathrm{NaCl}$ and $\mathrm{KCl}$ increased VI compared to that of control. Nascimento and West (1998) illustrated that seed priming increased seed GP and VI due to supply mobilized food materials, activation and resynthesis of some enzymes and increased DNA and RNA synthesis. 


\section{CONCLUSION}

Results showed that drought stress declined growth parameters of corn seedling. Seed priming with Knano chelate and sulfate improved seedling traits and enhanced plant resistance to drought stress, obviously. Application of K-nano chelate for seed priming was more appropriate and efficient than $\mathrm{K}$-sulfate. Our findings revealed that it is favorable to propose suitable seed-priming methods for different plant seeds to encounter the challenges of the environment.

\section{ACKNOWLEDGMENTS}

The authors would like to thank Fasa University for providing financial support and the required facilities.

\section{REFERENCES}

Ahmed F., Baloch D.M., Sadiq S.A., Ahmed S.S., Hanan A., Taran S.A., Ahmed N., Hassan M.J. 2014. Plant growth regulators induced drought tolerance in sunflower (Helianthus annuus L.) hybrids. Journal of Animal and Plant Science, 24: 886-890

Basra S.M.A., Pannu I.A., Afzal I. 2003. Evaluation of seedling vigour of hydro and matriprimed wheat (Triticum aestivum L.) seeds. International journal of Agriculture and Biology, 5: 121- 123

Bewley J.D., Black M. 1994. Physiology of Development and Germination, $2^{\text {nd }}$ Ed., New York, Plenum Press, 233 str.

Bhatt R.M., Srinivasarao N.K. 2005. Influence of pod load on response of okra to water stress. Indian Journal of Plant Physiology, 10: 54-59

Bradford K.J. 1990. A water relations analysis of the seed germination rates. Plant Physiology, 94: 840849. DOI: $10.1104 /$ pp. 94.2 .840

Cakir R. 2004. Effect of water stress at different development stages on vegetative and reproductive growth of corn. Field Crops Research, 89: 1-16. DOI: $10.1016 /$ j.fcr.2004.01.005

Cantliffe D.J., Fischer J.M., Nell T.A. 1984. Mechanism of seed priming in circumventing thermo dormancy in Lettuce. Plant Physiology, 75: 290-294. DOI: 10.1104/pp.75.2.290

Chapman S., Crossa J., Basford K.E., Kroonenberg P.M. 1997. Genotype by environment effects and selection for drought tolerance in tropical maize. II. Three mode pattern analysis. Euphytica, 95:11-20. DOI: 10.1023/A:1002922527795
De F., Kar R.K. 1994. Seed germination and seedling growth of mung bean (Vigna radiate) under water stress included by PEG-6000. Seed Science and Technology, 23: 301-304

Ebadi M.T., Azizi M., Farzaneh A. 2011. Effect of drought stress on germination factors of four improved cultivars of German Chamomile (Matricaria recutita L.). Journal of Plant Production, 18: 119-132

Ellis R.A., Roberts E.H. 1981. The quantification of ageing and survival in orthodox seeds. Seed Science and Technology, 9: 373-409

Elouaer M.A., Hannachi C. 2012. Seed priming to improve germination and seedling growth of safflower (carthamus tinctorius) under salt stress. Eurasian Journal of Biological Science, 6: 76-84. DOI: 10.5053/ejobios.2012.6.0.9

Farooq M., Basra S.M.A., Saleem B.A., Nafees M., Chishti S.A. 2005. Enhancement of tomato seed germination and seedling vigor by osmopriming. Pakistan Journal of Agricultural Science, 42: 36-41

Gallardo K., Claudette J., Groot S.P.C., Puype M., Demol H., Vandekerckhove J., Job D. 2001. Proteomic analysis of Arabidopsis seed germination and priming. Plant Physiology, 126: 835-848. DOI: 10.1104/pp.126.2.835

Hardegree S.P., Emmerich W.E. 1994. Seed germination response to polyethylene glycol solution depth. Seed Science and Technology, 22: $1-7$

Hegarty T.W. 1978. The physiology of seed hydration and dehydration, and the relation between water stress and the control of germination: a review. 
Plant, Cell Environment, 1: 101-119. DOI: 10.1111/j.1365-3040.1978.tb00752.x

Hopper N.W., Overholt J.R., Martin J.R. 1979. Effect of cultivar, temperature and seed size on the germination and emergence of soy beans (Glycine max L. Merr.). Annals of Botany, 44: 301-308.

ISTA (International Seed Testing Association) .1996. International rules for seed testing. Seed Science and Technology, 24: 155-202

Jajarmi V. 2012. Effect of drought stress on germination indices in seven wheat cultivars ( $T$. aestivum L.). Journal of Agronomy and Plant Breeding, 8: 183192

Jisha K.C., Vijayakumari K., Puthur J.T. 2013. Seed priming for abiotic stress tolerance: an overview. Acta Physiologia Plantarum, 35: 1381-1396. DOI: 10.1007/s11738-012-1186-5

Job D., Capron I., Job C., Dacher F., Corbineau F., Come D. 2000. Identification of germinationspecific protein markers and their use in seed priming technology. In: Black $\mathrm{M}$, Bradford $\mathrm{KJ}$, Vazguez-Ramos J (Eds) Seed biology: advances and applications. CAB International, Wallingford, pp 449-459. DOI: 10.1079/9780851994048.0449

Karavani B., Tavakkol Afshari R., Majnoon Hosseini N., Moosavi S.A. 2013. Effect of drought stress on germination characteristics of Tanacetum polycephalum under different temperature regimes. International Journal of Agriculture and Crop Science, 6: 1018-1023

Keshavarz R., Keikhah M., Chaichi M.R., Ansari M. 2013. Effect of different levels of salinity and drought stress on seed germination characteristics and seedling growth of forage turnip (Brassica rapa L.). Iranian Journal of Field and Crop Science, 43: 661-671

Khakshoor Moghadam Z., Lahouti M., Ganjeali A. 2011. Effects of drought stress induced by polyethylene glycol on germination and morphophysiological characteristics of Dill Anethum graveolens L.). Journal of Horticultural Science, 25: 185-193

Kusaka M., Lalusin A.G., Fujimura T. 2005. The maintenance of growth and urgor in pearl millet (Pennisetum glaucum L. Leeke) cultivars with different root structures and osmo-regulation under drought stress. Plant Science, 168: 1-14. DOI: 10.1016/j.plantsci.2004.06.021

Lisar S.Y.S., Motafakkerazad R., Hossain M.M., Rahman I.M.M. 2012. Water Stress in Plants: Causes, Effects and Responses, Water Stress. By Ismail Md. Mofizur Rahman (Eds.), ISBN: 978-
953-307-963-9, InTech, Available from: http://www.intechopen.com/books/waterstress/water-stress-inplants-causes-effects-andresponses

Maraghni M., Gorai M., Neffati M. 2010. Seed germination at different tempratures and water stress levels, and seedling emergence from different depths of Ziziphus lotus. South African Journal of Botany, 76: 453-459. DOI: 10.1016/j.sajb.2010.02.092

Massarat N., Siadat A., Sharafizadeh M., Habibi B. 2014. The effect of priming on germination and growth of maize hybrid SC704 in drought and salinity stress condition. Plant Ecophysiology, 15: $13-25$

McDonald M.B. 2000. Seed priming. In: Black M., Bewley J.D. (Eds) Seed technology and its biological basis. Sheffield Academic Press, Sheffield, pp. 287-325

Mexal J., Fisher J.T., Osteryoung J., Reid C.P.P. 1975. Oxygen availability in polyethylene glycol solutions and its implications in plant-water relations. Plant Physiology, 55:20-24. DOI: 10.1104/pp.55.1.20

Michel B.E., Kaufmann M.R. 1973. The osmotic potential of polyethylene glycol 6000. Plant Physiology, 51: 914-916. DOI: 10.1104/pp.51.5.914

Nascimento W.M., West S.H. 1998. Priming and seed orientation affect emergence and seed coat adherence and seedling development of muskmelon transplants. Horticultural Science, 33: 847-848

Natale E., Zalba S.M., Oggero A., Reinoso H. 2010. Establishment of Tamarix ramosissima under different conditions of salinity and water availability: Implications for its management as an invasive species. Journal of Arid Environment, 74:1399-1407.

DOI: 10.1016/j.jaridenv.2010.05.023

Osborn D.J. 1993. Function of DNA synthesis and in dormancy. Seed Science Research, 3: 43-53

Pan X.Y., Wang G.X., Yang H.M., Wei X.P. 2003. Effect of water deficits on within-plot variability in growth and grain yield of spring wheat in North West China. Field Crop Research, 80: 195-205. DOI: 10.1016/S0378-4290(02)00175-2

Patane C., Cavallaro V., Cosentino S.L. 2009. Germination and radicle growth in unprimed and primed seeds of sweet sorghum as affected by reduced water potential in $\mathrm{NaCl}$ at different tempratures. Indian Journal of Crop Production, 30: 1-8. DOI: 10.1016/j.indcrop.2008.12.005

Acta agriculturae Slovenica, 107 - 1, marec 2016 
Patane C., Saita A., Sortino O. 2012. Comparative effects of salt and water stress on seed germination and early embryo growth in two cultivars of sweet sorghum. Journal of Agronomy and Crop Science, 199: $\quad 30-37$. DOI: $\quad 10.1111 / \mathrm{j} .1439$ 037X.2012.00531.x

Rane J., Maheshwari M., Nagarajan S. 2001. Effect of pre-anthesis water stress on growth, photosynthesis and yield of six wheat cultivars differing in drought tolerance. Indian Journal of Plant Physiology, 6: 53-60.

Rodriguez P., Torrecillas A., Morals M.A., Ortuno M.F., Blanco M.J.S. 2005. Effects of $\mathrm{NaCl}$ salinity and water stress on growth and leaf water relations of Asteriscus maritimus plants. Environmental Experimental Botany, 53: 113-123. DOI: 10.1016/j.envexpbot.2004.03.005

Saeidi M., Ahmadi A., Postini K., JAhansooz M.R. 2007. Evaluation of germination traits of different genotypes of wheat in osmotic stress situation and their correlations with speed of emergence and drought tolerance in farm situation. Journal of Science and Technology of Agricultural and Natural Resources, Soil and Water, 11: 281-294 (in Persian)

Sankar B., Jaleel C.A., Manivannan P., Kishorekumar A., Somasundaram R., Panneerselvam R. 2007. Drought-induced biochemical modifications and proline metabolism in Abelmoschus esculentus (L.) Moench. Acta Botanica Croatica, 66: 43-56
Scott S.J., James R.A., Williams W.A. 1984. Review of data analysis methods for seed germination. Crop Science, 24:1192-1199. DOI: 10.2135/cropsci1984.0011183X002400060043x

Sedghi M., Nemati A., Esmaielpour B. 2010. Effect of seed priming on germination and seedling growth of two medicinal plants under salinity. Emirates Journal of Food and Agriculture, 22: 130-139. DOI: 10.9755/ejfa.v22i2.4900

Sivritepe H.O., Eris A., Sivritepe N. 1997. The effects of priming treatments on salt tolerance in melon seeds. Acta Horticulture, 492: 287-295

Van Gastel A.J.G., Pagnotta M.A., Porceddu E. 1996. Seed Science and Technology, CARDA, Jodhpur, $311 \mathrm{p}$

Vasquez-Ramos J.M., Sanchez M.D.I. 2004. The cell cycle and seed germination. Seed Science Research, 13: 113-130. DOI: 10.1079/SSR2003130

Young J.A., Evans R.A., Roundy B., Cluff G. 1983. Moisture stress and seed germination. USDA, Science and Education Administration, Publication Armw-36

Zahedifar M. 2013. Corn germination and seedling characteristics as influenced by seed- priming with potassium nano chelate and potassium sulfate fertilizers under salinity stress conditions. Thai Journal of Agricultural Science, 46: 219-229 